\title{
Pentingnya Materi Lingkungan dalam Pembelajaran Bahasa Indonesia di Sekolah
}

\author{
Deby Willy Amanda
}

\section{debywilly08@gmail.com}

Kebersihan lingkungan selalu menjadi masalah di Indonesia dari masa ke masa, kurangnya kesadaran dalam diri setiap manusia menjadi salah satu penyebabnya. Upaya untuk menciptakan rasa tanggung jawab dan kesadaran akan kebersihan lingkungan hendaknya harus di ajarkan sejak dini. Kebersihan lingkungan ini juga hendaknya diajarkan di lingkungan sekolah yang dibimbing oleh pihak guru. Salah satu upaya untuk menerapkan tentang kebersihan lingkungan ini dengan memberikan materi tentang lingkungan pada proses pembelajaran, dengan begitu diharapkan siswa dapat menerapkan hasil dari pembelajaran tersebut pada lingkungannya.

Menurut Nkwetisma C M (dalam Ramadhan et al, 2019), pendidikan lingkungan merupakan upaya bersama yang diselenggarakan secara sadar untuk mengajarkan atau menarik perhatian manusia tentang bagaimana lingkungan alam berfungsi dan bagaimana manusia tersebut dapat mengelola dan melindunginya. Menurut Jacobs G M (dalam Ramadhan et al, 2019), tujuan dari pendidikan lingkungan adalah membuat siswa berpartisipasi dalam menjaga lingkungan. Menurut Kollmuss A dan Agyeman J, Schultz P W, Shriver C, Tabanico J J, dan Khazian A M, Xehua Z, dan Çokçaliskan H and Çelik Ö (dalam Ramadhan et al, 2019) mengatakan bahwa agar siswa dapat berperan serta dalam menjaga lingkungan, penting untuk mengembangkan pengetahuan tentang lingkungan, kepedulian lingkungan dan perubahan perilaku terhadap lingkungan.

Lingkungan sangat mempengaruhi kemampuan berbahasa dan tutur seseorang. Menurut Ramadhan (2019), kesantunan dalam bertutur sangat tergantung juga pada masyarakat dan lingkungannya. Kesantunan berbahasa tidak hanya sebatas perkataan lisan atau tulisan saja, namun juga prilaku, sikap, dan perbuatan juga menggambarkan seseorang itu memiliki kesantunan berbahasa yang baik atau tidak (Astuti, Ramadhan, Ermanto, 2012).

Menurut Uyar (dalam Ramadhan et al, 2019), penggunaan tema lingkungan dalam pembelajaran teks dapat memicu minat siswa untuk belajar bahasa dan secara implisit dapat meningkatkan pengetahuan siswa tentang lingkungan. Memadukan pendidikan lingkungan dalam pembelajaran bahasa tidaklah mudah. Guru harus memiliki pengetahuan dan kesiapan yang diperlukan tentang lingkungan agar kegiatan di kelas efisien. Menurut Sukma (2019), dalam pembelajaran bahasa Indonesia sebagai guru menghadapi masalah dan proses 
pembelajaran, terutama pada aspek kognitif, yaitu kurangnya pemahaman guru dalam mengajar. Menurut Ramadhan, Ghani, Amelia (2018) model pembelajaran yang inovatif mampu meningkatkan hasil belajar peserta didik. Model pembelajaran sangat berpengaruh terhadap hasil belajar siswa, guru dapat memilih model pembelajaran yang bervariasi (Fitri, Ramadhan, Afnita, 2018).

Dalam materi lingkungan ini, guru juga dapat memadukannya dengan media pembelajaran yang lebih menarik, agar siswa tidak bosan mempelajari materi lingkungan ini. Media pembelajaran yang akan dibuat juga perlu adanya pemahaman guru dalam menggunakan media dan kebijakan apa yang harus diketahui dalam penggunaan media digital secara bijak (Ramadhan, Sukma, Indriyani, 2019). Menurut Sukma, Mahjuddin, Habibi (2019), guru dan praktisi pendidikan dapat menggunakan literasi media yang dikembangkan dalam mencapai tujuan pembelajaran.

Menurut Obasoro, Oyinloye, dan Ilensami (dalam Ramadhan et al, 2019), siswa perlu memiliki pengalaman dalam mengambil inisiatif sehubungan dengan persyaratan yang mendesak di bidang tantangan global dan masyarakat. Menurut Rozana, Ramadhan, Basri (2018), untuk mencapai tujuan pendidikan diperlukan komunikasi dua arah antara guru dan siswa selama proses pembelajaran. Hal ini bertujuan agar siswa termotivasi untuk lebih aktif dalam mengemukakan pendapat, bertanya, dan kreatif selama proses pembelajaran. Menurut Bergman B,G (dalam Ramadhan et al, 2019), guru memainkan peran penting dalam mengajarkan pendidikan lingkungan hidup. Misalnya, dalam pembelajaran bahasa Indonesia, guru dapat memberikan materi lingkungan kepada siswa agar siswa lebih memahami contoh yang konkret yang bisa ditemui di sekitarnya, atau dengan adanya materi lingkungan dalam pembelajaran bahasa Indonesia memudahkan siswa dalam menuangkan ide dalam bentuk tulisan, sehingga keterampilan menulis akan lebih baik lagi. Maka materi lingkungan dalam pembelajaran di sekolah sangat penting dalam pembelajaran bahasa Indonesia. Pengembangan model, media, atau materi pembelajaran dapat dilakukan agar pendidikan lingkungan dapat diterapkan khususnya di sekolah (Sukma, Ramadhan, Indriyani 2020).

Berdasarkan angket yang saya sebarkan kepada 30 mahasiswa yang berasal dari UNP, USU, dan UMSU, diperoleh data sebagai berikut. Butir 1 bahwa materi lingkungan sangat berkaitan dengan pembelajaran bahasa Indonesia yang menyatakan, (60\%) setuju, (40\%) sangat setuju, (0\%) kurang setuju, dan (0\%) tidak setuju. Butir 2 bahwa lingkungan mempengaruhi kemampuan berbahasa seseorang yang menyatakan, (50\%) sangat setuju, $(50 \%)$ setuju, (0\%) kurang setuju, dan (0\%) tidak setuju. Butir 3 bahwa materi lingkungan dalam pembelajaran bahasa Indonesia dapat menumbuhkan kepedulian siswa terhadap 
lingkungan yang menyatakan, (56,7\%) setuju, (40\%) sangat setuju, (3.3\%) kurang setuju, dan $(0 \%)$ tidak setuju. Butir 4 bahwa upaya-upaya pelestarian lingkungan dapat dilakukan melalui teks-teks bacaan dalam pembelajaran bahasa Indonesia yang menyatakan, (60\%) setuju, $(26,7 \%)$ sangat setuju, $(13,3 \%)$ kurang setuju, dan $(0 \%)$ tidak setuju.

Butir 5 bahwa materi lingkungan dalam pembelajaran bahasa Indonesia dapat dijadikan inspirasi siswa dalam memproduksi teks yang menyatakan, $(60 \%)$ setuju, $(36,7 \%)$ sangat setuju, $(3,3 \%)$ kurang setuju, dan $(0 \%)$ tidak setuju. Butir 6 bahwa siswa dapat memproduksi teks laporan hasiil observasi dengan mengamati langsung lingkungan sekitarnya yang menyatakan, (50\%) sangat setuju, $(46,7 \%)$ setuju, $(3,3 \%)$ kurang setuju, dan $(0 \%)$ tidak setuju. Butir 7 bahwa siswa dapat menampilkan drama dengan tema lingkungan dalam pembelajaran bahasa Indonesia yang menyatakan, (53,3\%) setuju, (40\%) sangat setuju, $(6,7 \%)$ kurang setuju, dan $(0 \%)$ tidak setuju. Butir 8 bahwa guru juga memiliki peran penting dalam pengerjaan materi lingkungan pada pembelajaran bahasa Indonesia yang menyatakan, $(50 \%)$ sangat setuju, (50\%) setuju, (0\%) kurang setuju, dan (0\%) tidak setuju. Butir 9 bahwa guru dan siswa harus bekerja sama dalam melestarikan lingkungan kelas dan lingkungan sekolah yang menyatakan, (60\%) sangat setuju, (36,7\%) setuju, (3,3\%) kurang setuju, dan $(0 \%)$ tidak setuju. Butir 10 bahwa kurikulum seharusnya lebih banyak memasukkan materi lingkungan dalam pembelajaran bahasa Indonesia yang menyatakan, $(53,3 \%)$ setuju, $(40 \%)$ sangat setuju, $(6,7 \%)$ kurang setuju, dan $(0 \%)$ tidak setuju.

Berdasarkan hasil penelitian diatas dapat disimpulkan bahwa materi lingkungan dalam pembelajaran bahasa Indonesia memang sangat penting di sekolah dan diperlukan bagi pihak siswa, guru, seluruh perangkat pendidikan dalam artian sampai kepada staf tata usaha, pustakawan, dan pihak keamanan sekolah. Dengan mempelajari dan menerapkan materi lingkungan terutama dalam pembelajaran bahasa Indonesia, akan menjadikan semua pihak tersebut akan semakin menjaga dan melestarikan lingkungannya, menumbuhkan sikap peduli terhadap situasi dan kondisi lingkungan sekitar. 


\section{DAFTAR PUSTAKA}

Astuti, R, Ramadhan. S, dan Ermanto. (2012). Kesantunan Berbahasa Dalam Talkshow “Neo Democrazy Di Metro Tv. Jurnal Pendidikan Bahasa dan Sastra Indonesia. Vol. 1 No. 1.

Fitri, Margin Mulya, Syahrul R., dan Afnita. (2018). Pengaruh Model Discovery Learning Berbantuan Media Gambar Berseri Terhadap Keterampilan Menulis Teks Eksplanasi Siswa Kelas VIII SMP Negeri 25 Padang. Jurnal Pendidikan Bahasa dan Sastra Indonesia. Vol. 1 no. 7.

Ramadhan, Syahrul, Erizal Ghani, dan Siska Amelia. (2018). The effects of cooperative learning model type TPS and reading habits toward skills in writing short story reviews text. Internasional Conferences on Languange, and Education. Advances in Social Science, Education and Humanities, 263.

Ramadhan, S, Sukma, E, dan Indriyani. V. (2019). Environmental Education and Disaster Mitigation Through Language Learning. IOP Conference Series: Earth and Environmental Science, Vol. 314.

Ramadhan, S, Sukma, E, dan Indriyani. V. (2019). Teacher competence in utilizing digital media literacy in education. Journal of Physics: Conference Series. 1339 (2019) 012111.

Rozana, Rita, Ramadhan, Syahrul, dan Basri, Irfani. (2018). Kontribusi Motivasi Belajar dan Penguasaan Kosakata Terhadap Keterampilan Menulis Teks Eksposisi Siswa SMA. Lingua. Volume XIV. Nomor 1.

Sitombo, Roli dan R. Syahrul. (2019). Tindak Tutur Ilokusi Pendakwah Dalam Program Damai Indonesiaku di TV One. Jurnal Kajian Bahasa, Sastra Indonesia, dan Pembelajarannya, Vol. (3)2, 251.

Sukma, E., Mahjuddin, R., dan Habibi, M (2019). Preliminary Research of Media Literacy Development. Advances in Social Science, Education and Humanities Research. Volume 337.

Sukma, E. (2019). Problem in oral language teaching in primary school. Seventh international conference on languages and arts (ICLA 2018). Atlantis press.

Sukma, E., Ramadhan, S., \& Indriyani, V. 2020. Integration Of Environmental Education In Elementary Schools. IOP Conf. Series: Journal of Physics: Conf. Series 1481, pp. 2-3. 